\title{
Mengkiritisi Banyaknya Peraturan Daerah Bermasalah
}

\author{
Muhammad Thalhah \\ Universitas Bojonegoro
}

\begin{abstract}
Parallel with the regional autonomy in the post-reformation era, regional governments and parliaments enthusiastically produce regulation as tools of fund-raising to support their regional development projects and welfares. Unfortunately, these promulgated regulations have, to large extent, breached both formal and substantial principles as legal products have to be. As a consequence, these legal products are, indeed, contra productive with the ends of achieving people welfares.
\end{abstract}

Keywords: Regional autonomy, regulations, welfares.

ukum negara substansinya tidak lahir

prinsipnya adalah memberikan keadilan - Tsecara alamiah, melainkan direkonstruksi secara sosial. Pengertian direkonstruksi tentu saja terkait dengan kebutuhan tetapi tetap dalam koridor substansinya. Oleh karena itu hukum menjadi media pengarah masyarakat yang popular dengan istilah law as tool of social engineering yang tidak lain hasil pemikiran (Rosco Pound, 1972) Teori ini meyakini bahwa dalam membangun masyarakat yang tertib menuju keadilan, hukum memegang peranan sangat penting. Atas dasar itulah hampir tidak ada sebuah masyarakat tanpa hukum mampu mewujudkan ketertiban dan keadilan. Sebagian pakar hukum Indonesia menganut teori ini, diantaranya Mochtar Kusumaatmadja (1987).

Pada hakikatnya law as tool of social engineering mengandung filosofi dan tujuan (substansi) yang sangat luas. Hukum dalam hal ini bertujuan selain menertibkan dan membangun konstruksi masyarakat, yang seluas mungkin bagi masyarakat itu sendiri. (Nasikun, 1989). Atas dasar itulah ketika lahir UU No. 22 Tahun 1999 tentang Pemerintahan Daerah dan UU No. 25 Tahun 1999 tentang Perimbangan Keuangan Pusat dan Daerah yang kemudian diganti dengan UU No.32 dan 33, sebenarnya yang dirasakan pada kondisi sebelum adanya undang-undang itu adalah munculnya berbagai gap atau kesenjangan (Syamsuddin, 1999) (bahkan menjauhkan masyarakat dari rasa keadilan dan munculnya kesimpangsiuran) pengaturan tentang daerah (Yosep, 2004). Bahkan yang ekstrim munculnya reaksi berlebihan di mana sejumlah provinsi ingin memisahkan diri dari negara kesatuan, sebuah upaya yang jika dilacak tak lain akibat perlakuan yang tidak adil (faktor ekonomi) dan diskriminatif dalam berbagai aspek. Kasus semacam ini masih terjadi bahkan di depan Presiden SBY di Ambon (Maluku) awal bulan Juni 2007 lalu, serta dalam acara Konggres 
Rakyat Papua di bulan yang sama (dua hari kemudian) dimana seremoni acara pembukaannya diawali dengan tarian yang mengusung bendera Bintang Kejora secara atraktif, sebuah "teror" bagi negara kesatuan. Sementara di Aceh menyambut Pilkada muncul pula partai lokal yang mengusung ideologi GAM dengan simbol benderanya sebagai wujud perlawanan (ancaman) terhadap NKRI.

\section{Relevansi Otonomi Daerah}

Otonomi dalam pengertiannya yang paling luas, merupakan kecenderungan umum di dalam dunia global dewasa ini, yang di dalamnya ada upaya-upaya berbagai pihak baik pada tingkat teoritis maupun praksis bagi pembebasan dari berbagai otoritas dan pengaturan, dalam rangka mendapatkan pengaturan diri sendiri, baik pada tingkat individu, golongan, daerah, kelompok, komunitas, masyarakat, agama, ras, suku, atau negara.

Otonomi, dalam perspektif hukum Indonesia adalah amanat konstitusi sesuai pasal 18 UUD 1945, sementara derivasi dari konstitusi itu sesuai sejarah perkembangannya dimulai dari UU No. 1 Tahun 1945 , yang terus mengalami penyempurnaan dengan diundangkannya UU No. 22 Tahun 1948, UU No. 1 Tahun 1957, UU No. 18 Tahun 1965, UU No. 5 Tahun 1974 hingga UU No. 22 Tahun 1999/UU.No.32 Tahun 2004 (Yosep, 2000).

Memasuki era reformasi, keinginan kuat melepaskan diri dari sistem lama yang sentralistik menemukan momentumnya yang terefleksi dengan diberlakukannya UU No. 22 Tahun 1999 tentang Pemerintahan Daerah yang di antaranya mengatur secara spesifik otonomi daerah, dan UU No. 25 Tahun 1999 tentang Pengaturan Perimbangan Keuangan Pusat dan Daerah.
Tuntutan terhadap otonomi daerah ini mulamula muncul cukup keras termasuk ancaman disintegrasi dari beberapa daerah provinsi (Syamsuddin, 1999). Otonomi daerah pada esensinya adalah perwujudan keinginan mengatur diri sendiri dengan titik berat daerah kabupaten. Namun, sayangnya setelah berjalan hampir sepuluh tahun, otonomi daerah berkembang kearah melampaui prinsip otonomi itu sendiri. Tampaknya otonomi di antaranya masih dipahami secara sempit sebagai kebebasan mengatur diri sendiri. Akibatnya otonomi daerah berjalan seolah tanpa bingkai kemanusiaan dan terutama tanpa bingkai hukum. Disinyalir telah muncul "raja-raja kecil" di daerah. Secara konkret hal ini terlihat dari tingginya kasus korupsi yang tidak hanya dilakukan oleh eksekutif tetapi telah merasuki pula kalangan legislatif (Kompas, 20 Juni 2004). Tercatat hingga bulan Juni 2006 lalu tidak kurang dari 120 kasus di 26 DPRD Provinsi yang melibatkan sekitar 1.478 (anggota DPRD) mulai dari Banda Aceh, Sumatera Barat (termasuk Kabupaten Payakumbuh), Sumatera Selatan, Riau, Lampung, DI Yogyakarta, Sulawesi Selatan, Kalimantan Barat (Kabupaten Singkawang), Jawa Timur, Jawa Barat (Kabupaten Ciamis dan Kabupaten Garut) dan lain-lain.

Melihat perjalanan otonomi daerah pasca UU No. 32/2004 dan UU No.33/2004 tak pelak lagi, sangat dibutuhkan komitmen moral dan ketegasan hukum agar pelaksanaannya dapat berjalan dengan baik. Cukup banyak agenda yang mesti dilakukan agar masing-masing bidang yang saat ini tengah mekar di Indonesia terjaga semangatnya seperti pelaksanaan demokrasi, penegakan hukum, pemerintahan yang bersih, kehidupan yang lebih berbudaya dan meratanya keadilan sosial. 
Mengkiritisi Banyaknya Peraturan Daerah Bermasalah; Muhammad Thalhah

Tulisan berikut mengkaji banyaknya Peraturan Daerah (Perda) yang terbukti bermasalah bukan hanya dari segi semangatnya tetapi dari segi teori hukum itu sendiri.

\section{Perda-Perda Bermasalah}

Diantara komitmen hukum yang harus ditegakkan segera adalah problem banyaknya Peraturan Daerah (Perda) yang dibuat hanya sekadar memanfaat euforia reformasi. Perda-perda ini jika dikritisi justru kontra-produktif dengan semangat otonomi daerah dan yang lebih ekstrim lagi sejumlah Perda itu telah melanggar hirarki bahkan melanggar konstitusi. Singkatnya Perdaperda itu diistilahkan oleh sejumlah pakar hukum sebagai Perda bermasalah.

Dari data yang ada tahun 2004 untuk mengatur satu bidang investasi saja terdapat 1.066 Perda yang masuk kategori penghambat investasi,termasuk Perda soal KUKM yang dinilai menghambat pertumbuhan koperasi, usaha kecil dan menengah. Oleh karena itu Menteri Negara Urusan Koperasi dan UKM Suryadharma Ali mengatakan paling tidak ada 30 Perda yang perlu dicabut ditahun 2007 ini karena jelasjelas tidak sejalan dengan substansi iklim ekonomi rakyat yang kita inginkan dan bertentangan dengan UU Investasi yang berada (hirarki)di atasnya. Dari jumlah 1.066 Perda itu telah dibatalkan oleh Mendagri sebanyak 469 Perda. Pada penelitian tentang pengaturan hutan, penelitian Sudi Fahmi (Fahmi, 2006) juga menemukan bahwa dari 50 Perda yang mengatur tentang Kehutanan di Propinsi Riau hampir 50 \% ternyata telah melanggar hirarki sesuai UU No.10 Tahun 2003. Ironisnya Menteri Kehutanan pada bulan Juli 2007 menemukan lagi Perda yang melegalkan pembakaran hutan untuk membuka lahan baru yang jelas-jelas merusak lingkungan sekaligus melanggar UU tentang Lingkungan (Kompas, 31 Juli 2007). Juga ditemukan peraturan daerah di daerah lain problemnya kurang lebih sama. Diperkirakan jika pihak Departemen Dalam Negeri lebih serius meneliti setiap Perda-perda di bidang lain, maka akan lebih banyak Perda-perda bermasalah ditemukan dan akan lebih banyak pula yang "wajib" dicabut karena melanggar hirarki atau substansinya bertentangan dengan UU lain.

Jika disederhanakan isi Perda-perda bermasalah itu pada umumnya bersifat pragmatis yaitu ingin mendapatkan sebanyak-banyaknya pendapatan daerah terutama PAD, namun mengabaikan aspek etika, persyaratan formil dan materiil sebuah produk hukum.

\section{Tarik Ulur Kewenangan}

Jika dilacak ke belakang mengapa kontroversi berbagai produk hukum bermasalah itu terjadi, secara normatif sebagai akibat tarik ulur antara pusat dan daerah. Pada satu sisi, negara kesatuan menghendaki enheidstaat, sedangkan di sisi lain otonomi daerah menghendaki autonomistaat. Tarik ulur ini memang telah terjadi sejak awal berdirinya Negara Kesatuan Republik Indonesia, bahkan sejak penjajahan Belanda.

Ternyata membuat sebuah kebijakan hukum dalam bingkai kebhinekaan bukan perkara mudah, terutama justru pada aspek teknisnya. Apalagi aspek politis sangat kental berlindung dibalik isu demokratisasi, hak asasi manusia, pemerataan, kesenjangan dan lain-lain yang harus melindungi indigenous society yang justru sering berujung pada gerakan separatis yang memancing emosi nasionalisme. Yang jelas tarik ulur kewenangan ini telah berdampak 
UNISIA, Vol. XXX No. 65 September 2007

kepada inkonsistensi dalam penegakan hukum sekaligus kontra-produktif terhadap nilai-nilai filosofis, politis, yuridis, dan sosiologis bagi kemajuan masyarakat itu sendiri.

Dalam konteks inilah tarik ulur kewenangan itu harus diakhiri karena jelas merugikan atau kontra-produktif (bersifat elitis) dengan cita-cita untuk memajukan masyakarat. Sebagai catatan, implikasi dari setiap inkonsistensi sebuah produk hukum adalah: Pertama, akan memunculkan problem ketidakpastian hukum. Kedua, implikasi teknisnya akan merusak objek dari regulasi itu sendiri. Sebagai contoh bila regulasinya di bidang kehutanan, maka akan merusak alam, hutan (kekeliruan dalam pengelolaan hutan) dan sulit mencari siapa yang bertanggungjawab. Ketiga, memunculkan konflik kepentingan (conflict of interest) yang penyelesesaiannya pun ternyata tidak mudah.Contoh konflik kepentingan di daerah Papua antara PT. Freeport dengan masyarakat setempat, antara pemerintah dengan Freeport dan antara Freeport dengan pemerintah. ${ }^{1}$

Lebih dari itu saatnya kita mengkritisi setiap kelahiran produk hukum tidak hanya di pusat tetapi juga di daerah dengan menghidupkan lembaga pengujian materi setiap regulasi, tak terkecuali Peraturan Daerah. Dengan begitu maka sebuah produk regulasi jelas konsepnya, jelas hirarkinya, jelas pula visi, misi dan arahnya, serta memenuhi persyaratan formil dan materiil sebuah produk hukum.

\section{Melembagakan Pengujian Materi Peraturan Perundang-undangan}

Banyaknya Perda bermasalah harusnya menjadi pelajaran berharga bagi kita bahwa konsep negara hukum yang kita anut belum sepenuhnya konsisten dengan cita-cita konstitusi. Untuk itulah sangat penting melembagakan atau mengoptimalkan pengujian materi regulasi. Dengan adanya pengujian itu, setiap produk regulasi akan terseleksi secara cermat, jelas, dan tidak menimbulkan implikasi yang luas. Oleh karena itu, hendaknya kita kembali memperhatikan persyaratan teoritis agar regulasi itu tidak asal jadi.

Secara teoritis hak pengujian dibagi dalam dua bagian, yakni:

(1) Hak menguji formil (formale toetsingrech) adalah wewenang untuk menilai, apakah suatu produk legislatif seperti undang-undang (UU) atau Perda, misalnya terjelma melalui caracara (prosedur) sebagaimana telah ditentukan/diatur dalam peraturan perundang-undangan yang berlaku ataukah tidak. Dari pengertian hak menguji formil di atas, tampak jelas bahwa yang dinilai atau diuji adalah tatacara (prosedur) pembentukan suatu undang-undang/perda, apakah sesuai ataukah tidak dengan apa yang telah ditentukan/digariskan dalam peraturan perundang-undangan.

(2) Hak menguji materiil (materiel toetsingrecch) yakni suatu wewenang untuk menyelidiki dan kemudian menilai, apakah suatu peraturan perundang-undangan menyelidiki dan kemudian menilai, apakah suatu

${ }^{1}$ Konflik kepentingan di sini: pertama, dari segi administratif,misalnya, izin pengusahaan hutan. Di satu sisi izin itu dikeluarkan oleh pemerintah, namun di sisi lain, eksistensi masyarakat adat (hak ulayat) yang notabene mengklaim kepemilikan yang diberi izin itu lalu bertahan dengan hak-haknya. Di sini konflik dapat menjadi tak terkendali. 
Mengkiritisi Banyaknya Peraturan Daerah Bermasalah; Muhammad Thalhah

peraturan perundang-undangan isinya sesuai atau bertentangan dengan peraturan yang lebih tinggi derajatnya, serta apakah suatu kekuasaan tertentu (verordenende macht) berhak mengeluarkan suatu peraturan tertentu. Jadi, hak menguji materiil ini berkenaan dengan isi dari suatu peraturan dalam hubungannya dengan peraturan yang lebih tinggi derajatnya (hirarki).

Hal yang juga terkait dengan pengujian ini, sebelum dibuat hendaknya memperhatikan asas-asas dalam perundangan sesuai dengan teori perundangan, yaitu memperhatikan asas formil dan asas materiilnya yang meliputi:

1. asas tujuan jelas (Het beginsel van duideijke doelstelling); ketepatan letak peraturan, tujuan khusus peraturan akan dibentuk, tujuan bagian-bagian dari peraturan perundang-undangan yang akan dibentuk.

2. asas lembaga yang tepat (Het beginsel van het juiste orgaan); asas perlunya pengaturan timbul karena selalu ada alternatif lain untuk menyelesaikan suatu masalah pemerintahan selain dengan membentuk peraturan perundang-undangan. Pembentukan peratutan perundang-undangan ini merupakan alternatif lain dalam pengaturan.

3. asas dapat dilaksanakan (Het beginsel van uitvoerbaarheid); asas yang menghendaki suatu peraturan dapat ditegakkan. Tidak akan ada gunanya merumuskan berbagai macam aturan dalam berbagai norma jika pada akhirnya norma tersebut tidak dapat ditegakkan. Salah satu penegakan tersebut melalui penjatuhan sanksi tegas terhadap pelanggar peraturan.

4. asas konsensus (Het beginsel van de concensus); adanya kesepakatan rakyat untuk melaksanakan kewajiban dan menanggung akibat yang ditimbulkan oleh peraturan perundangundangan yang bersangkutan. Asas ini dapat dicapai jika dilakukan desiminasi secara terarah. Persoalannya jika peraturan yang diberlakukan pada saat yang bersamaan sangat banyak jumlahnya, maka keberadaan asas ini tidak efektif.

Sementara itu, asas-asas materiil perundang-undangan yang harus diperhatikan adalah:2

1. asas kejelasan terminologi dan sistematika (Het beginsel van de duidelijke terminologie en duidelijke systematiek).

Asas terminologi lebih tepat jika dimasukkan ke dalam teknik penyusunan peraturan perundangundangan, karena asas ini lebih menekankan kepada teknik merancang kata-kata, struktur dan susunan peraturan sehingga pada akhirnya membentuk norma yang mengikat.

2. Asas bahwa peraturan perundangundangan mudah dikenali (Het beginsel van den kenbaarheid).

Asas dapat dikenali sangat penting artinya terutama bagi peraturan perundang-undangan yang membebani masyarakat dengan berbagai kewajiban. Apabila suatu peraturan perundang-undangan tidak dikenali dan diketahui setiap orang, terlebih bagi orang yang berkepentingan, maka ia akan kehilangan tujuannya sebagai peraturan.

2Pasal 5 dan Penjelasannya, UU Nomor 10 Tahun 2004 
UNISIA, Vol. XXX No. 65 September 2007

3. Asas persamaan (Het rechts gelijkheids beginsel).

Asas ini mendasari bahwa tidak boleh adanya peraturan perundang-undangan yang ditujukan hanya kepada sekelompok orang tertentu, karena hal ini akan mengakibatkan adanya ketidaksamaan dan kesewenangwenangan di depan hukum terhadap anggota-anggota masyarakat.

4. Asas kepastian hukum (Het rechtszekerheids beginsel).

Asas kepastian hukum merupakan asas yang mendasar, karena merupakan salah satu sendi negara berdasarkan atas hukum. Oleh karena itu, setiap peraturan yang dibentuk harus jelas. Tidak dapat merumuskan pemberlakuan surut suatu norma hukum (retroaktif), apabila yang bersifat pembebanan (seperti, pajak, retribusi) karena bertentangan dengan asas kepastian hukum. Pengecualian terhadap norma yang bersifat retroaktif dapat dilakukan tetapi harus sangat hati-hati, jelas dan transparan.

5. Asas pelaksanaan hukum sesuai dengan keadaan individual (Het beginsel van de individuele rechtsbedeling).

Asas ini bermaksud memberikan penyelesaian yang khusus bagi hal-hal atau keadaan-keadaan tertentu, sehingga dengan demikian peraturan perundang-undangan atau Perda dapat juga memberikan jalan keluar (solusi) selain bagi masalah-masalah umum, juga bagi masalah-masalah khusus. Asas ini sebaiknya diletakkan pada pihak-pihak yang melaksanakan/ menegaskan peraturan perundangundangan tetapi dengan petunjukpetunjuk yang jelas dalam peraturan

perundang-undangan yang bersangkutan itu sendiri.

Lalu yang tak kalah pentingnya adalah pembuatan produk hukum harus tetap mengacu kepada UU Nomor 10 Tahun 2004 terutama Pasal 7 ayat (1) tentang hirarki yang harus ditaati yaitu:

a. Undang-Undang Dasar Negara Republik Indonesia Tahun 1945.

b. Undang-undang/Peratutan Pemerintah Pengganti Undang-undang

c. Peraturan Pemerintah.

d. Peraturan Presiden

e. Peraturan Daerah

\section{Penutup}

Centang perenangnya wajah Perdaperda itu jika dilacak di lapangan akibat kebutuhan pragmatis daerah yang ingin segera mendapatkan dana sebesarbesarnya untuk membiayai pembangunan daerahnya. Sayangnya, kebutuhan pragmatis itu lalu tanpa memperhatikan "rambu-rambu hukum". Jika dibiarkan, Perda-perda itu justru akan membuat kehidupan kita menjadi semakin semrawut karena isi Perda tersebut sesungguhnya kontra-produktif dengan keinginan masyarakat, di samping substansinya tidak sesuai dengan hirarki yang ada. Bahkan lebih jauh jika dibiarkan akan merusak tatanan negara hukum yang kita inginkan.

Penulis menyarankan, agar saatnya Depdagri atau lembaga berwenang/terkait menghidupkan lembaga semacam Penguji Peraturan Perundang-undangan (hak uji/judicial review) agar Perda-perda itu tidak liar.

Penulis juga menyarankan, agar setiap pemerintah daerah yang ingin membuat Perda terlebih dahulu mempersiapkan Draf Akademis. Dengan adanya draf akademis itu, akan teruji apakah materinya baik/layak 
Mengkiritisi Banyaknya Peraturan Daerah Bermasalah; Muhammad Thalhah

ataukah tidak, akan terlihat pula substansinya apakah sudah mentaati asas formil dan asas materiil, ruang lingkup dan seterusnya.

\section{Daftar Pustaka}

Data ICW Jakarta, 2006.

J. Kaloh, 2003, Kepala Daerah, Pola Kegiatan, Kekuasaan dan Perilaku Kepala daerah dalam Pelaksanaan Otonomi Daerah, Jakarta:Gramedia.

Jawa Pos, 17 Juli 2007.

Josep Riwu Kaho, 2002, Prospek Otonomi Daerah, Jakarta:Rajawali Press.

Kompas 23 Juli 2007.

Kompas, 20 Juni 2004.

Kompas, 31 Juli 2007.

Lili Rasjidi dan B. Arief Shidarta,1987, Filsafat Hukum, Mazhab dan Refleksinya,Bandung: Rosda Karya.

Nasikun, Substansi Hukum, Majalah Keadilan. Yogyakarta: FH UII edisi Juni 1989.
Mahendra Putra Kurnia,dkk,2007. Pedoman Naskah Akademik PERDA Partisipatif, Yogyakarta: Kreasi Total Media.

Roscoe Pound, 1976, Pengantar Filsafat Hukum, Bharata, Jakarta 1972. Lihat juga Mochtar Kusumaatmadja, Masyarakat dan Pembinaan Hukum Nasional, Bandung: Bina Cipta,.

Sudi Fahmi, 2006, Konsistensi Hukum Penyerahan Kewenangan Antara Pemerintah Pusat dan daerah Dalam Penyelenggaraan Pemerintahan Daerah, Disertasi pada Program IImu Hukum UII Yogyakarta.

Syamsuddin Haris, et.al,1999, Indonesia di Ambang Perpecahan, Jakarta: Erlangga.

UU No. 32 dan 33 tahun 2004.

UU Nomor 10 Tahun 2004

Yasraf Amir Piliang, 2004, Posrealitas Kebudayaan dalam Era Posmetafisika, Yogyakarta: Jalasutra. 